\title{
Polyherbal hypocholesterolemic supplement lowers egg yolk cholesterol without affecting performance and egg quality in layers
}

\author{
V.D. LONKAR, A.S. KADAM, V.R. PATODKAR, S.N. JADHAV, R.P. KOLHE AND SHIVI MAINI
}

\begin{abstract}
This study was designed to evaluate efficacy of polyherbal hypocholesterolemic supplement AV/HLP/16 (test compound) on serum and egg yolk cholesterol levels and egg quality parameters in layers. One hundred and twenty healthy White Leghorn (BV 300 strain) of 54 weeks age were randomly divided into four treatments $\left(\mathrm{T}_{0}, \mathrm{~T}_{1}, \mathrm{~T}_{2}, \mathrm{~T}_{3}\right)$; subdivided into three replicates with ten birds in each replicate for a period of five weeks $\left(54^{\text {th }}\right.$ to $58^{\text {th }}$ weeks of age). $\mathrm{T}_{0}$ was the control supplied with commercial basal diet without addition of test compound. $\mathrm{T}_{1}, \mathrm{~T}_{2}$ and $\mathrm{T}_{3}$ were supplemented with test compound in basal diet @ 1.0, 1.5 and $2.0 \mathrm{~kg} /$ ton of feed, respectively. Weekly feed intake, daily egg production, egg weights, egg yolk total cholesterol, egg weight, shape index, yolk weight, albumen weight, shell weight, shell thickness was recorded. Significant reduction in serum cholesterol and egg yolk cholesterol $(\mathrm{P}<0.05)$ was observed in treatment groups. Polyherbal AV/HLP/ 16 supplementation in layers did not impart any beneficial or deleterious effect on feed intake, feed efficiency, hen day egg production or egg quality traits viz., egg weight, shape index, yolk weight, and albumen weight except shell thickness. Polyherbal hypocholesterolemic supplement AV/HLP/16 @ 1.0, 1.5 and $2.0 \mathrm{~kg}$ per ton of feed reduced egg yolk cholesterol with better egg shell thickness without affecting the performance as well as egg quality parameters in layers.
\end{abstract}

KEY wORDS : Layer, Hypocholesterolemic supplement, Cholesterol

How to Cite ThIS PAPer : Lonkar, V.D., Kadam, A.S., Patodkar, V.R., Jadhav, S.N., Kolhe, R.P. and Maini, Shivi (2014). Polyherbal hypocholesterolemic supplement lowers egg yolk cholesterol without affecting performance and egg quality in layers. Res. J. Animal Hus. \& Dairy Sci., 5(2) : 126-130.

\footnotetext{
- MEMBERS OF RESEARCH FORUM

Address for correspondence :

V.D. Lonkar, Department of Poultry Science, KNP College of Veterinary Science (MAFSU), Shirwal, SATARA (M.S.) INDIA

Email : vijulvet@ rediffmail.com

Associated Authors' :

A.S. Kadam, Department of Poultry Science, KNP College of Veterinary Science (MAFSU), Shirwal, SATARA (M.S.) INDIA

V.R. Patodkar, Department of Physiology, KNP College of Veterinary Science (MAFSU), Shirwal, SATARA (M.S.) INDIA

S.N. Jadhav, Department of Biochemistry, KNP College of Veterinary Science, Shirwal (MAFSU), SATARA (M.S.) INDIA

R.P. Kolhe, Department of Veterinary Public Health, KNP College of Veterinary Science (MAFSU), Shirwal, SATARA (M.S.) INDIA

Shivi Maini, Ayurvet Ltd., SOLAN (H.P.) INDIA
} 